\title{
Retraction Note: Eficacy of pentoxifylline treatment for neonatal sepsis: a meta- analysis of randomized controlled studies
}

Jun Tian ${ }^{1}$, Peifang Shen ${ }^{1}$, Kaiyu Pan ${ }^{1}$ and Qiong Zhou ${ }^{2^{*}}$

Retraction Note: Ital J Pediatr 45, 108 (2019)

https://doi.org/10.1186/s13052-019-0697-8

The Editor-in-Chief has retracted this article because it contains material that substantially overlaps with an article by Peiyun Peng and Yunfeng Xia [1]. All authors agree to this retraction.

\footnotetext{
Author details

'Department of pediatrics, The First people's Hospital of Xiaosha, Hangzhou, China. ${ }^{2}$ Department of pediatrics, Children's Hospital of Hangzhou, No 318 Chaowang Road, Hangzhou 310005, Zhejiang Province, People's Republic of China.
}

Published online: 12 February 2021

\section{Reference}

1. Peng P, Xia Y. Influency of pentoxifylline treatment for neonatal sepsis: a meta-analysis of randomized controlled studies. Hong Kong J Emerg Med. 2019;9:1024907919864248 https://doi.org/10.1177\%2F1024907919864248.

Full list of author information is available at the end of the article

(c) The Author(s). 2021 Open Access This article is licensed under a Creative Commons Attribution 4.0 International License, which permits use, sharing, adaptation, distribution and reproduction in any medium or format, as long as you give appropriate credit to the original author(s) and the source, provide a link to the Creative Commons licence, and indicate if changes were made. The images or other third party material in this article are included in the article's Creative Commons licence, unless indicated otherwise in a credit line to the material. If material is not included in the article's Creative Commons licence and your intended use is not permitted by statutory regulation or exceeds the permitted use, you will need to obtain permission directly from the copyright holder. To view a copy of this licence, visit http://creativecommons.org/licenses/by/4.0/. The Creative Commons Public Domain Dedication waiver (http://creativecommons.org/publicdomain/zero/1.0/) applies to the data made available in this article, unless otherwise stated in a credit line to the data. 